\title{
Social Rehabilitation Through a Community-Based Rehabilitation Lens: Empowerment, Participation and Inclusion of the Elderly Long-Term Unemployed in the Re-employment Process
}

\author{
Riitta-Liisa Kokko $(\mathbb{D} \cdot$ Kaija Hänninen $(\mathbb{D} \cdot$ Maritta Törrönen $(\mathbb{C}$
}

Received: 17 June 2020/Accepted: 31 July 2020/Published online: 10 August 2020

(C) The Author(s) 2020

\begin{abstract}
This research examined social rehabilitation in the context of the components of communitybased rehabilitation (CBR) through the experiences of elderly long-term unemployed in the re-employment process in Finland. Two questions were posed: 'What kinds of experiences do the elderly long-term unemployed have of social rehabilitation?' and 'What can the key components of CBR-empowerment, participation and inclusion-offer for the re-employment process?' We analysed social rehabilitation through the experiences of 15 elderly long-term unemployed individuals who had been employed in the intermediate labour market, and results showed they had experienced social rehabilitation in diametrically opposed ways, both positive and negative. The positive experiences included hopefulness, partnership, and re-employment, while a negative outlook, being left alone in the workplace community, and exclusion from the labour market were found amongst the negative experiences. Based on the results, we built a practical model of social rehabilitation, which we called the EPI model.
\end{abstract}

R.-L. Kokko $(\varangle) \cdot$ K. Hänninen · M. Törrönen Faculty of Social Sciences, University of Helsinki, Unioninkatu 37, P.O. Box 54, 00014 Helsinki, Finland e-mail: riitta-liisa.kokko@helsinki.fi

K. Hänninen

e-mail: hanninen.kaija@gmail.com

M. Törrönen

e-mail: maritta.1.torronen@helsinki.fi
Keywords Social rehabilitation - Community-based rehabilitation - Empowerment - Participation . Inclusion · Long-term unemployed

\section{Introduction}

The EU's strategies for employment are activation policy and active inclusion, underpinned by the idea that all citizens should have the opportunity to work and participate in society [1-3]. The two primary approaches to activation policy are work first and human capital, the latter of which is more common in the Nordic countries [4-7]. The work first approach presumes that any job is better than no job and, thus, prioritises labour market attachment, while the human capital approach focuses on enhancing the social and professional skills of the unemployed and, consequently, encouraging voluntary integration into working life [4].

In addition to activation policies, social services are a prerequisite for integrating groups with complex social problems into the labour market, and activation practices based on social services can be described as inclusive [8]. Despite the activation policy, the elderly and workers with little education are not the labour market's desired workforce, even though the policy's objective is to extend working careers $[9,10]$. This phenomenon means that the unemployed and, in 
particular, the elderly long-term unemployed encounter significant difficulties in achieving re-employment.

One embodiment of the activation policy is to employ the long-term unemployed in the transition labour market (TLM). One form of the TLM is the intermediate labour market (ILM), meaning wage working between unemployment and open labour markets. The concepts of the TLM and ILM underline changes, new types of risks, and the polarisation of citizens in the labour markets. One main criticism concerns the risk to citizens of increasing social segregation, differentiation, and individualisation [11]. Within the ILM, one form of coaching implementation is Supported Employment (SE), which is based on the practice of Individual Placement and Support (IPS) in the workplace [12]. The process of SE consists of quick job placement, guidance, support, and coaching at work under the guidance of a job coach $[13,14]$.

In terms of an individual's resources, health, physical, mental, and social functions form the basis of working capacity [9]. Several analyses and literature reviews have shown that unemployed individuals fare worse than those who are employed, both mentally and physically [15-17]. Psychosocial issues, such as substance abuse, mental health issues, and accumulated social problems, can hinder the ability of long-term unemployed individuals to find work $[18,19]$, while deficiencies in vocational skills are often intertwined with everyday life management problems and health-related limitations, further reducing employment prospects $[9,19]$.

Employment mitigates exclusion and poverty and increases social participation, welfare, social capacity, and life management (see [20], and regaining employment has a demonstrably positive effect on an unemployed person's quality of life [21], helping to elevate his or her health status, especially mental health [22]. Evidence has also been found that reemployment improves self-perception within a short time. Thus, labour market participation should be considered as a therapeutic intervention among unemployed persons [23].

In Finland, the threat of social exclusion may be a criterion for initiating rehabilitation [24]. Unemployed people who have different types of social, psychosocial, and health problems require support and social rehabilitation to return to working life. Social rehabilitation is a multidimensional entity that takes into account the client, family, and wider community, with the goal of enabling change, growth, and recovery [25].

Rehabilitation should be customer-oriented in its development and interventions must focus more on the psychosocial problems of the unemployed [18, 26]; however, little is known about how various activating and employment services affect the well-being of the elderly long-term unemployed specifically [10, 23, 27, 28]. This study aims to increase knowledge about this group and the potential of communitybased rehabilitation (CBR) in social rehabilitation in the context of unemployed individuals in the ILM. Our research took place in Finland and represents the Nordic welfare society.

Theoretical framework: Community-based rehabilitation

Since the 1980s, the goal of rehabilitation has been defined as a process of social integration, which stems from the inclusion that occurs from participating in the functioning of a community and society [26]; World Health Organization [WHO] [29]. In 2019, the WHO authored a strategy for rehabilitation, equalisation of opportunities, poverty reduction, and the social inclusion of people with disabilities, as well as the employment of persons with disabilities.

The aim of a community strategy for rehabilitation is to increase inclusion and prevent exclusion. CBR consists of five elements: health, education, income, a social aspect, and empowerment. The first four follow the four divisions of rehabilitation-medical, educational, professional, and social rehabilitation-while empowerment establishes their foundation. Experts originally developed CBR to improve the social status of people with disabilities through medical rehabilitation, full participation, and access to equal opportunities [30, 31], and this strategy was not originally created to address the needs of the chronically unemployed.

CBR guidelines define rehabilitation for people with disabilities as comprising the following components: inclusion, participation, sustainability, empowerment, self-advocacy, and a barrier-free environment (WHO [32, 33]. In our research, we focused on the experiences of the elderly long-term unemployed in terms of empowerment, participation, and inclusion in society because, according to the WHO [32, 33], these 
are the key components of CBR. From the perspective of social rehabilitation, empowerment represents the individual level, participation represents the community level, and inclusion represents the societal level of rehabilitation (World Health Organization [33] 2019).

The first key component, empowerment, is a central method and a goal to be achieved to enhance individuals' and families' quality of life and human rights [26]. Empowerment is a process in which individuals address their own problems and work to solve them [34] and is based on the human experience of being able to cope with difficulties and bring about one's desired changes in living conditions or life situations $[34,35]$.

The second key component of CBR, participation, has social, emotional, and intellectual features. Social participation implies a sense of togetherness with other people and an ability to influence the group's decisions [36], emotional participation is the feeling of being important and valuable [34], and intellectual participation is the sense of being seen, heard, and understood in society. Through participation, individuals reach the point where they can influence their own lives [37].

The third key component, inclusion, is often understood to mean that everyone has the opportunity to contribute to society through working life. A person has a sense of being included in their community and society when they work, and, thus, the unemployed lack this sense of work-related inclusion [38]. Inclusion might be an individual's profound sense of membership in a community and of the opportunity to have a constructive role in collective processes [36].

Social rehabilitation is part of the Finnish National Programme of Rehabilitation, and it plays a central role in the Act on Social Care [24]; however, the application of the law is still unequal. The Act on Rehabilitative Work [39] is intended to improve individuals' control over their lives, increase working capacity, and create conditions for work with small financial compensation. The implementation of both laws is the responsibility of each municipality. Social rehabilitation is used to enable people who have become severely socially excluded to participate in society by strengthening their social interactions and functional capacities [40] and as a method to support and coach the long-term unemployed when they return to work. In other countries, this support is variously referred to as 'social care work', 'social support', 'preventive social work', and 'social pedagogy' [41], unpublished).

\section{Background}

The National Full-Employment Project, funded by the State of Finland, was initially implemented in the Finnish municipality of Paltamo (2009-2013). The Paltamo employment trial (see [42] sought to employ all 16-63-year-old unemployed job seekers in the municipality, including those with substance abuse and mental health problems. The goal was to end highlevel, multigenerational unemployment and prevent the exclusion of the long-term unemployed via wage work in the ILM. Participation was obligatory; refusal to work was followed by sanction and quarantine. This trial also implemented some SE features. This kind of operating model produces better employment outcomes than a long training period before employment [14].

No previous studies of the experiences of social rehabilitation or CBR in the ILM have been found. The work in the Paltamo trial was performed in workshops in a large central building, as well as in outside jobs such as wage-subsidy work, temporary work, and rental work. In wage-subsidised work, the state pays employers for hiring the long-term unemployed for time-limited work. In the trial, unemployment and social benefits were converted into the wage and the employees were provided with work-community support and job coaching that would enable them to enter the open labour market; however, there was a great need for coaching but few job coaches. The project implemented a total of 440 employment contracts, and the largest age group comprised individuals of 50-64 years old.

The purpose of this study was to increase knowledge about the experiences of social rehabilitation and potentials of community-based rehabilitation in the reemployment process of the ILM and to examine the experiences of the elderly unemployed in the reemployment process to determine if the key components of CBR have some new and important considerations to offer for social rehabilitation practices. Thus, the following research questions were proposed:

Q1: What kinds of experiences do elderly longterm unemployed persons have of social rehabilitation? 
Q2: What can the key components of CBRempowerment, participation and inclusion-offer in the re-employment process?

\section{Methods}

Data collection

The Finnish Institute for Health and Welfare coordinated the Paltamo research, and one of the present study's authors was involved in collecting interview material. The theme interviews were based on the experiences of the elderly long-term unemployed in the Paltamo employment trial in 2010-2011, and were conducted with the first 15 volunteers who responded to the invitation. Interviewees were aged 50-64, the largest age group in the employment trial, and were employed in 2009-2013. The average age of the interviewees was 56.4 years; 8 were men and 7 were women.

In the interviews, the respondents were asked about their life situations, work history, unemployment, working in the ILM, social rehabilitation, support in the trial, well-being at work, job-seeking, re-employment, and future goals. The interviews were audiorecorded and then transcribed, and the research material from the 15 interviewees, though relatively small, was rich.

Data analysis

A content analysis method was used [43, 44], and the theoretical framework for the analysis was based on the CBR key components, which were combined with the functional individual, community, and societal levels of rehabilitation [45, 46].

Our analysis focused specifically on the social rehabilitation experiences of empowerment, participation, and inclusion among elderly long-term unemployed people. We first carefully read the material several times, organized the text, and classified and structured the experiences of the participants according to the key components, considering what the material contained, what it said, and in what way (see [44]. Second, we categorised the background information into themes (including life situation, previous work history, work experience, and participants' expectations for the employment trial). Third, we analysed the interviewees' individual experiences and the significance of the social rehabilitation by classifying them based on the three components (empowerment at the individual level, participation at the community level, and inclusion at the societal level). This phase revealed the participants' contradictory opinions as they described their experiences primarily as positive or negative, offering a variety of views on the social rehabilitation. Finally, we summarised the interviewees' original expressions, conceptualised them, and placed them on a concept map.

The study was conducted with ethical principles in mind: interviewees were informed of the study and its objectives and gave informed consent for their participation in the research and the use of the interview data. It was ensured that interviewees remained anonymous.

The different stages of the study were carefully described by illuminating the voices of the interviewees with honesty and respect. Sentences were combined without changing the context, and we used ' (... ' to indicate exclusions we made without changing the interviewee's meaning. The data excerpts included herewith are translations from Finnish into English of direct quotations from the interviews, with only filler words omitted. Abbreviations were used to denote individual interviewees (P1, P2, etc.).

Almost all of the interviewees were part-time workers in the trial. The length of their unemployment periods varied: eight had been unemployed under 2 years and seven for more than 2 years. Nine people had vocational education, one had a university qualification, and five had no vocational education. While their backgrounds varied, nearly all reported various illnesses, financial struggles, and issues with work performance. Two interviewees mentioned substance abuse, five spoke about severe depression, one had recently been released from prison, and four described difficulty engaging with the workplace community due to social anxiety. Five expressed concerns about the risk of social exclusion. 


\section{Results}

Empowerment: Hopefulness or a negative outlook

In the ILM, the trial involved SE job coaching from both peers and professionals; many of these coaches were former unemployed peers without training as tutors. The interviewees received support, guidance, job coaching, and the opportunity to discuss any issues weighing on their minds:

For many, it has been important to listen, talk, maybe give some guidance. One important part of this [work] has been meeting people. (P5)

In the workshops, the interviewees undertook simple, practical work with shorter working hours. Most were pleased that they had secured paid employment for a long period, and many stated that working brought a regular income and a sense of meaning into their everyday lives. They described the growth of their self-worth, self-confidence, and resulting assertiveness as important and how the experiences of success at work increased their trust in their own survival and created positive future prospects:

It really is the income and that sense of your own power-that you can manage on your own. It raises self-confidence. And if there is something meaningful to do, then you feel comfortable at work and [there are] all the social contacts. It is important for a human's sense of value to feel that you're being useful. (P8)

The interviewees noted that meaningful work and meeting people were empowering experiences, while the feelings that their activities were important increased their hopefulness and were also empowering. They further described how their self-esteem, satisfaction, and competence grew, and they received positive feedback, which boosted their resources. The positive experiences at work prompted the employees to seek new work opportunities and plan their futures:

It was customary for me to go to work for 40 years, so that gap between the ears [attitude] changes so that unemployment is discouraging and working increases self-esteem. ... It's always like, you get something done, and it encourages you and gives you a sort of satisfied feeling, like I got that done, too. (P12)
Identifying their own strengths and resources was another empowering process for the elderly reemployed and helped them regain their self-respect. Most of the interviewees were satisfied with the trial and committed to their work. They also became assertive and defended their rights in the workplace:

Then, when I kept really firm, I did manage to reduce this [the number of working hours]. I have kind of developed these ways to survive [in the workplace]. (P1)

Despite these empowering experiences, some interviewees still had negative experiences and suffered from a lack of motivation. Some were critical of the trial and activation policy because they were made to participate in the ILM against their will: as the trial was not voluntary, it did not have a rehabilitative meaning for everyone:

If there was no forced labour, I wouldn't be here anymore... Not even greeted. It has been really hard and stressful being here at work. Getting out of here is good. (P6)

My attitude has become negative...you have to focus on sitting in this workplace [without doing anything]. (P14)

Many were dissatisfied and found the modest jobs meaningless and frustrating. They also found it difficult to adapt to the workplace community due to its oppressive and depressing atmosphere; instead of inducing feelings of empowerment, this consumed personal resources and weakened their work motivation. Although they were paid, their skills did not improve via the simple work, and their self-esteem suffered. Some interviewees were left without meaningful work, support, or guidance. Without any positive feedback and attention to their work, they did not become empowered:

At first, I was terribly motivated, but then at some point, I started to get frustrated. Then, the salary supplement was taken away when I had no training in the field. At that point, I became terribly depressed, and I had a lack of motivation ... If there is a terribly distressing atmosphere in the workplace, you can't work there. (P9)

In these instances, this disappointment at work and the trial itself were not rehabilitative but deflating. The 
experience did not open up prospects or hopefulness, and the participants expressed a negative outlook for their present and future.

In summary, empowerment at the individual level meant that the persons received appreciation, positive feedback, new resources at work, and guidance and support as needed, as well as the opportunity to influence their work tasks. The meaningful work gave them work motivation, self-confidence, and assertiveness, which increased their hopefulness and trust in their own survival. Negative experiences, on the other hand, were not empowering, as degrading and frustrating work eroded individuals' work motivation. Working without any positive feedback or attention was discouraging, and the oppressive, depressing atmosphere consumed their personal resources.

\section{Participation: Partnership or being left alone}

In terms of participation, the experiences of the interviewees were partly positive and partly negative. Positive experiences were characterised by a view of partnership and working with peers, while negative experiences were characterised by being left alone in the work community.

In the case of partnership, the workplace community helped the interviewees feel they belonged to a peer group and were appreciated, rather than simply being considered 'unemployed'. Workmates in the workshops formed regular contacts and a daily, solid social network. The interviewees who felt that they had such social relationships in the workplace described the atmosphere as encouraging and supportive and experienced that peer support promoted their psychosocial well-being:

However, every day there are people, other people, with whom I speak. After all, it's good in that sense. At least it affects that mental wellbeing. (P3)

At the workplace, the interviewees could talk with their peers about work, life, and personal matters. Belonging to a group offered many opportunities to find new social relationships and, consequently, prevented loneliness and social exclusion. The interviewed women emphasised the significance of social relationships, while the men focused on sharing their experiences of work with their peers:
When I went there [wage-subsidy work], I recognised that now I am where I need to be. Those talks and stuff, somehow, it immediately struck me that it was comfortable with this group... In this employment situation, it is now worth doing things and thinking about what to do. (P12)

Many interviewees described a sense of togetherness with peers, which represented social participation. Some told of their experiences of being a valuable employee and a member of the work community, describing their emotional participation. A few interviewees referred to the ability to influence their own lives or their re-employment, which depicted intellectual participation.

At the same time, many interviewees had negative experiences of being left alone in the work community. They felt that the work atmosphere was neither encouraging nor supportive and mentioned a lack of leadership, support, or guidance from peers or job coaches. This meant, despite the goals, that support or job coaching did not materialise for them. The reasons for such experiences varied: some felt that they were excluded from the work community, while others withdrew themselves from social contact because of social fears. These experiences of being outside the work community did not allow for the social and community rehabilitation of these individuals:

When a meeting is held in the workplace, we don't belong to the crowd. We are told, 'You do not need to stay here'; 'You can go away'. (P13)

A few interviewees had difficulty joining the workplace activities and said they were excluded from the community group. Management strove to prevent power struggles and bullying, but many of the interviewees felt that they remained invisible, devoid of appreciation and encouragement. The experience provoked anxiety and fear; rather than being rehabilitative, it was discouraging:

We had the sort of fear here at one time, and then there were those bullies, who were taken really seriously. And the director specifically emphasised that there are none [bullies] in our building, we don't tolerate them. ... It does feel like being oppressed now and then.... They leave me out of everything, and they won't even help me, even though I need some help. (P9) 
A few of the interviewees brought up their own tendency to withdraw, and, for that reason, these individuals would have benefited from social rehabilitation. Those who did not feel like part of the workplace experienced social anxiety, and, since they found meeting new people stressful, they would have preferred to find employment in a small workshop with fewer employees:

I'm of the withdrawn sort. It's terribly difficult for me to go into the staff facilities or the break room. Most of the work was done [alone] by myself, the work community was not there. No feedback on work. (P6)

In summary, participation at the community level resulted in most interviewees feeling that they were valuable employees and members of the work community. At the time, the atmosphere was encouraging and supportive and promoted their psychosocial wellbeing, while peer support, job coaching, and belonging to a group offered opportunities to develop new social relationships and, thus, prevented loneliness and social exclusion. Conversely, a few felt they had been left out of the work community and found this experience depressing. The work atmosphere was not open and supportive for these interviewees, and some were left alone, bullied, or without access to peer support and job coaching. Experiences of being left alone without appreciation and partnership induced discouragement and loss of trust, and this situation was not rehabilitative.

Inclusion: Re-employment or a return to unemployment

The employment trial in the ILM was intended to support the re-employment of individuals through the SE-process involving a quick job placement, guidance, support, and coaching at work (see [13, 14]; the official goal was to help all individuals to return to the open labour market:

I always have work to do. I'm a pretty reliable guy, I'll do what I promise. And then I'm fast. That's enough. Or that's what you should ask those who offer that job, isn't it? Or on the other hand, they wouldn't offer it if they didn't trust [me]... There are so many options, I haven't decided yet which one it is. (P12)
A few of the interviewees were confident of employment and had strong self-confidence in their ability to survive. They had high expectations of entering the open labour market through this employment trial, and the temporary work had strengthened their work and social skills. They recounted how they had become committed to the work, and they had gained vocational skills and valuable know-how. The elderly workers wanted to carry their share of societal responsibility, and some were willing to prioritise youth employment; they were concerned about the future of young people in the trial and wanted to pass along their skills to them:

I could get to work immediately if I searched for a welding site in southern Finland. Of course, I have some strengths and some languages; I speak English well. We have just the tacit knowledge of what hasn't been written. ... Ideally, there [in the workplaces] would be those older representatives who have that quiet knowledge. (P5)

Working and the salary received alleviated the interviewees' financial and social problems, boosted resources, and strengthened their participation in society. Activities in the work community had also reduced social fears and supported them in staying sober, thus, were socially rehabilitative; however, chronic health problems or substance abuse limited some participants' capacities to work and brought uncertainty to job seeking:

I have that problem, that major problem, the alcohol problem ... I see myself as an unreliable worker ... I have lost so many jobs because of the booze. (P10)

Some interviewees had already started their working life by 15-17 years old. At the time of the research, they had one to fifteen working years before retirement age and had still found the courage to start a job search; however, while motivated to seek employment, most of the participants did not believe their prospects were good:

I started work in the shop at the age of 15 and did 13 years there... I would have liked to go to high school, but then I didn't have a chance. (P1)

If only I could get my foot in the door somewhere, and then show those skills that I 
could perhaps still somehow do it, but if you can't get there, it's rather bad. (P13)

Most of the interviewees worked in workshops in the large central building. A few had found wage-subsidy work, such as temporary work, rental work, work trials, or retraining, and they had already moved towards the open labour market. These interviewees experienced that the employment trial had a positive meaning when it supported their skills and improved their employability. However, some had only negative options ahead. They did not want to look for work in the open labour market, even though they knew they would soon be unemployed again. Some of them felt that they had already given their work input and hoped to retire, while others felt that they were no longer needed or wanted in working life. Most interviewees said they had encountered age discrimination:

When you turn 50, they always ask right away how old you are. I have asked around and got the impression that I will not be hired again. (P4)

The interviewees who were over 50 with minimal educational backgrounds encountered unwanted situations in job-seeking, without further options. When the trial ended, seven of the interviewees had managed to enter the open labour market, working full-time, part-time, or in wage-subsidised positions. Three were waiting for retirement and four individuals returned to unemployment. For them, the trial was a disappointment. One individual had begun to study for a new professional qualification.

In summary, inclusion at the societal level encouraged many individuals to become committed to the work. They had valuable know-how and learned new skills that increased their employability, and they were motivated and active in seeking employment. They had expectations to enter the open labour market. On the other hand, the opposite of inclusion in working life was exclusion from the labour market, which meant the experience of lost opportunities, and these interviewees had encountered age discrimination in their job search in the open labour market. They felt that they were no longer needed or wanted in working life and were waiting for either retirement or to become unemployed again.

Table 1 shows the experiences in social rehabilitation of the interviewed elderly long-term unemployed individuals as part of the re-employment process, including the three key components of empowerment, participation, and inclusion in society.

Social rehabilitation had supported several interviewees in the re-employment process, although, for some, the trial proved to be a non-rehabilitative experience and, thus, did not support their return to work.

\section{Discussion and conclusion}

This qualitative study examined experiences of social rehabilitation and CBR's potential to support the elderly long-term unemployed in the re-employment process via interviews with 15 individuals who had only recently been employed in the intermediate labour market (ILM) in Finland's full employment project. In the rehabilitation research, we are the first to apply the components of empowerment, participation, and inclusion and analyse the material using these concepts in the social rehabilitation of the longterm unemployed. We examined these components at the individual, community, and societal levels.

According to our results, at the age of over 50, it is difficult for the elderly long-time unemployed to find employment in the open labour market if they have health problems, low levels of education, inadequate vocational training, long periods of unemployment and short-term work experiences. The situation is even worse if they have psychosocial problems, substance abuse, mental health problems, or depression. Social rehabilitation does not bring help and support to everyone, and the experiences of social rehabilitation in the studied trial ranged from positive to negative. Negative experiences and poor motivation seem to be related to the fact that a few interviewees were so close to retirement. Positive experiences, on the other hand, seem to be associated with the goal of getting back into the labour market.

Results showed that as empowerment is realised at the individual level, a person's hopefulness increases, and they take concrete steps to plan for their future. Empowerment and customer-oriented action seem to be crucial to the success of social rehabilitation (see also [26]. In contrast, the motivation of a frustrated or neglected person seems to be weak, and the outlook is negative, according to our findings. The feeling that one's own activities are important increases hopefulness and is empowering [34]. 
Table 1 Experiences of the elderly long-term unemployed of social rehabilitation

\begin{tabular}{|c|c|c|c|c|}
\hline & \multirow{2}{*}{$\begin{array}{l}\text { The key components of } \\
\text { CBR and activity levels }\end{array}$} & \multirow{2}{*}{$\begin{array}{l}\text { Background information and need } \\
\text { for social rehabilitation }(n=15)\end{array}$} & \multicolumn{2}{|c|}{ Participant experiences $(n=15)$} \\
\hline & & & Positive experiences & Negative experiences \\
\hline \multirow[t]{3}{*}{ Components } & $\begin{array}{l}\text { Empowerment at the } \\
\text { individual level }\end{array}$ & $\begin{array}{l}\text { Lack of personal motivation } \\
\text { Unclear future goals } \\
\text { Life management questions }\end{array}$ & $\begin{array}{l}\text { Hopefulness } \\
\text { To be seen and heard } \\
\text { Appreciation } \\
\text { Positive feedback } \\
\text { Good work } \\
\text { motivation } \\
\text { Self-confidence and } \\
\text { assertiveness } \\
\text { Encouraging } \\
\text { atmosphere } \\
\text { New resources } \\
\text { Plans for the future }\end{array}$ & $\begin{array}{l}\text { Negative outlook } \\
\text { Unpleasant experiences } \\
\text { Degrading work } \\
\text { Frustrating work } \\
\text { Weak work motivation } \\
\text { Lack of positive } \\
\text { feedback } \\
\text { Discouraging feelings } \\
\text { Oppressive and } \\
\text { depressive atmosphere } \\
\text { Deflation }\end{array}$ \\
\hline & $\begin{array}{l}\text { Participation at the } \\
\text { community level }\end{array}$ & $\begin{array}{l}\text { Psychosocial problems } \\
\text { Unemployment } \\
\text { Mental health and alcohol problems } \\
\text { Depression }\end{array}$ & $\begin{array}{l}\text { Partnership } \\
\text { Working with peers } \\
\text { Support and guidance } \\
\text { Valuable employee } \\
\text { Member of the work } \\
\text { community } \\
\text { Rehabilitative } \\
\text { atmosphere } \\
\text { Social relationships } \\
\text { Psychosocial well- } \\
\text { being }\end{array}$ & $\begin{array}{l}\text { Left alone in the work } \\
\text { community } \\
\text { Without peer support } \\
\text { Without guidance and } \\
\text { coaching } \\
\text { Feelings of being outside } \\
\text { the work community } \\
\text { Without encouragement } \\
\text { Work atmosphere was } \\
\text { not open and supportive } \\
\text { Bullying }\end{array}$ \\
\hline & $\begin{array}{l}\text { Inclusion at the societal } \\
\text { level }\end{array}$ & $\begin{array}{l}\text { The goal of work until retirement } \\
\text { age } \\
\text { Meaningful activity in society }\end{array}$ & $\begin{array}{l}\text { Re-employment } \\
\text { Rediscovering one's } \\
\text { place in society } \\
\text { Committed to work } \\
\text { Valuable know-how } \\
\text { New skills } \\
\text { Increased } \\
\text { employability } \\
\text { Motivation and } \\
\text { activation in job- } \\
\text { seeking } \\
\text { Obtain work in open } \\
\text { labour market }\end{array}$ & $\begin{array}{l}\text { Exclusion from the } \\
\text { labour market } \\
\text { Experiences of lost } \\
\text { opportunities } \\
\text { Age discrimination } \\
\text { No longer needed or } \\
\text { wanted in working life } \\
\text { Waiting for retirement } \\
\text { Return to unemployment }\end{array}$ \\
\hline
\end{tabular}

At the community level, interviewees' participation in the work community strengthened their social skills and community cohesion, and the employment had a rehabilitative meaning. The opposite situation instead meant leaving a person alone and their exclusion from social relationships in the work community. Our findings support the idea that re-employment and participation in the labour market encourage individuals as a form of therapeutic intervention [23].
At the societal level, the goal of rehabilitation is inclusion, which means finding one's own place and being active in society or working life. For the unemployed, finding a job in the open labour market requires the identification of their work skills and motivation. The opposite of inclusion is being excluded from working life, which can be due to low work motivation, poor work skills, various other problems, or age discrimination. Inclusion is 
important because it helps individuals regain selfrespect, which can be considered the ultimate goal of all action [47]. Social rehabilitation is successful in its mission when individual empowerment, participation, and inclusion take place in society. The experiences of rehabilitation, either positive or negative, have longterm consequences for an individual's life. The main idea of our article was to analyse the relevance of the CBR key components. More research on these components and their interrelationships is needed in practices of social rehabilitation and mental health rehabilitation with different client groups. The diametrical experiences and the factors behind them also require further investigation.

CBR's community strategy [48] has previously been implemented in disability services [49-51], although its strategy can also be transferred to social rehabilitation, which we explored through its key components of empowerment, participation, and inclusion. Our research concerned elderly long-term unemployed individuals and, based on its results, we constructed a social rehabilitation operating model, which we called the EPI model.

Social rehabilitation according to the EPI model comprised empowerment (E), participation (P), and inclusion (I). The goal of the empowerment is to create hopefulness. If it is operating appropriately according to the wishes of the participants, this will increase motivation, which, in turn, supports prospects to make plans for the future. Hopefulness is an important resource that sustains a person in difficult situations and is strongly associated with the aims and goals that individuals use to construct meaning in their lives [52].

We conclude that participation contains the meaning that everybody should have a social peer-network in which they really feel like they belong and are welcome, where the encounters are appreciative and respectful, and the atmosphere is encouraging and supportive. In action, it is important to ensure that everyone has social relationships, is able to participate, and that no-one is left out. The work offered to individuals should be customer-oriented because work seen as degrading reduces motivation and positive effects (see also [53].

According to our findings, inclusion means that everyone can find their own place in society, and individuals are motivated and active in seeking work and committed to working life. If age discrimination continues in the open labour market, it will remove possibilities for the social rehabilitation and employment of the elderly unemployed (see also [54]. Becoming re-employed results in many positive changes, such as a regular income, social relationships, and a purpose to one's everyday life [23].

Social rehabilitation is multi-dimensional, and clearly, no program can provide all aspects. Municipalities in Finland are responsible for developing and implementing social rehabilitation, which requires different content, but also common working models. Each CBR looks different because it is built as needed (see [48]; however, multi-professional cooperation across sectoral borders is necessary to develop social rehabilitation. The EPI model can also be applied to unemployed people of different ages and others in need of social rehabilitation and provides a good starting point for developing social rehabilitation, due to its development from research based on practical action from the participant's point of view.

The limitations of the study are the relatively small amount of interview material and that social rehabilitation was not a core theme of the Full-Employment Project. Although the trial and the research were conducted in Finnish conditions where a law on social rehabilitation is in force, CBR can provide a basis for applying, developing and studying a customer-oriented EPI model in the context of rehabilitation, employment and social services with different client groups in other countries. The central concept of EPIbased social rehabilitation is the positive experience of participants, particularly given that negative experiences have long-term consequences that can hinder rehabilitation. Work does not rehabilitate someone unless it is accompanied by personal elements that empower the individual, increase their participation and support their social inclusion.

Acknowledgements Open access funding provided by University of Helsinki and Finnish Institute for Health and Welfare

Open Access This article is licensed under a Creative Commons Attribution 4.0 International License, which permits use, sharing, adaptation, distribution and reproduction in any medium or format, as long as you give appropriate credit to the original author(s) and the source, provide a link to the Creative Commons licence, and indicate if changes were made. The images or other third party material in this article are included in the article's Creative Commons licence, unless indicated otherwise in a credit line to the material. If material is not 
included in the article's Creative Commons licence and your intended use is not permitted by statutory regulation or exceeds the permitted use, you will need to obtain permission directly from the copyright holder. To view a copy of this licence, visit http://creativecommons.org/licenses/by/4.0/.

\section{References}

1. Commission European. Active inclusion. Brussels: European Commission; 2016.

2. Heidenreich M, Graziano PR. Lost in activation? The governance of activation policies in Europe. Int J Soc Welf. 2014;23(S1):S1-5. https://doi.org/10.1111/ijsw.12099.

3. Van Berkel R, Hornemann Møller I. The concept of activation. In: van Berkel R, Hornemann Møller I, editors. Active social policies in the EU: inclusion through participation. Bristol: The Policy Press; 2002. p. 45-72.

4. Dean H. Re-conceptualising welfare-to-work for people with multiple problems and needs. J Soc Policy. 2003;32(3):441-59. S0047279403007062.

5. Lødemel I, Trickey H, editors. 'An offer you can't refuse': workfare in international perspective. Bristol: The Policy Press; 2001.

6. Tikkanen T, Nissinen K. Participation in job-related lifelong learning among well-educated employees in the Nordic countries. Int J Lifelong Educ. 2016;35(3):216-34. https:// doi.org/10.1080/02601370.2016.1165749.

7. Walker A. Commentary: the emergence and application of active aging in Europe. $\mathrm{J}$ Aging Soc Policy. 2008;21(1):75-93. 08959420802529986.

8. Heidenreich M, Aurich-Beerheide P. European worlds of inclusive activation: the organisational challenges of coordinated service provision. Int $J$ Soc Welf. 2014;23(S1):S6-22. https://doi.org/10.1111/ijsw.12098.

9. Gould R, Ilmarinen J, Järvisalo J, Koskinen S. editors. Työkyvyn ulottuvuudet. [The dimensions of one's capacity to work]. Hakapaino Oy. 2006.

10. Shemeikka R, Aho S, Jokinen E, Järnefelt N, Kaakinen M, Kivimäki R, Korkeamäki J, Mertala S, Mäkiaho A, Parkkinen M, Pitkänen S, Terävä K, Vuorento M. Työurien jatkaminen vaatii yhteisöllisyyttä ja yhteistoiminnallisuutta. [Continuing working careers requires communality and cooperation]. Valtioneuvoston selvitys- ja tutkimustoiminnan julkaisusarja 38/2017 [Government Research and Research Publication Series]. Valtioneuvoston kanslia. 2017.

11. Schmid G. Sharing risks of labour market transitions: towards a system of employment insurance. Br J Ind Relat. 2015;53(1):70-93. https://doi.org/10.1111/bjir.12041.

12. Becker DR, Drake RE. A working life: the individual placement and support (IPS) program. Hanover: New Hampshire-Dartmouth Psychiatric Research Center; 1993.

13. Bond GR, Dietzen LL, McGrew JH, Miller LD. Accelerating entry into supported employment for people with severe psychiatric disabilities. Rehabil Psychol. 1995;40(2):75-94. https://doi.org/10.1037/0090-5550.40.2. 75.
14. Bond GR, Drake RE, Mueser KT, Becker DR. An update on supported employment for people with severe mental illness. Psychiatr Serv. 1997;48(3):335-46. https://doi.org/10. 1176/ps.48.3.335.

15. Heponiemi T, Wahlström M, Elovainio M, Sinervo T, Aalto A-M, Keskimäki I. Katsaus työttömyyden ja terveyden välisiin yhteyksiin [An overview of the links between unemployment and health]. Työ- ja elinkeinoministeriön julkaisuja, Työ ja yrittäjyys [Publications of the Ministry of Employment and the Economy, Employment and Entrepreneurship].2008.

16. Paul K, Moser K. Unemployment impairs mental health: meta-analyses. J Vocat Behav. 2009;74(3):264-82. https:// doi.org/10.1016/j.jvb.2009.01.001.

17. Rüsch N, Malzer A, Oexle N, Waldmann T, Staiger T, Bahemann A, Wigand M, Becker T, Corrigan P. Disclosure and quality of life among unemployed individuals with mental health problems: a longitudinal study. J Nerv Ment Dis. 2019;207(3):137-9. https://doi.org/10.1097/NMD. 0000000000000914.

18. Ahs A, Burell G, Westerling R. Care or not care-that is the question: predictors of healthcare utilisation in relation to employment status. Int J Behav Med. 2012;19(1):29-38. https://doi.org/10.1007/s12529-010-9129-2.

19. Kerätär R. Kun katsoo kauempaa, näkee enemmän: Monialainen työkyvyn ja kuntoutustarpeen arviointi pitkäaikaistyöttömillä [When you look from a greater distance, you see more: Multi-disciplinary assessment of capacity to work and rehabilitation needs in the long-term unemployed]. Acta Universitatis Ouluensis. D 1340. Juvenes Print. 2016. http:// jultika.oulu.fi/files/isbn9789526210865.pdf.

20. Barnes M, Blom A, Cox K, Lessof C, Walker A. The social exclusion of older people: evidence from the first wave of the English Longitudinal Study of Ageing (ELSA). London: Office of the Deputy Prime Minister; The Institute for Fiscal Studies; 2006.

21. Carlier BE, Schuring M, Lötters FJB, Bakker B, Borgers N, Burdorf A. The influence of re-employment on quality of life and self-rated health, a longitudinal study among unemployed persons in the Netherlands. BMC Public Health. 2013;13(503):1-7. https://doi.org/10.1186/14712458-13-503.

22. Eliason M, Storrie D. Job loss is bad for your health: Swedish evidence on cause-specific hospitalization following involuntary job loss. Soc Sci Med. 2009;68(8):1396-406. https://doi.org/10.1016/j.socscimed. 2009.01.021.

23. Schuring M, Mackenbach J, Voorham T, Burdorf A. The effect of re-employment on perceived health. J Epidemiol Commun Health. 2011;65(7):639-44. https://doi.org/10. 1136/jech.2009.103838.

24. Finnish Government. The act on social care (1301/2014). 2014a. http://www.ilo.org/dyn/natlex/natlex4.detail?p_ lang=en\&p_isn=101111.

25. Shreedevi UA, Rosso D, Kalyanasundaram S. Application of the Strengths-based Approach in the Process of psychosocial Rehabilitation. In: Francis AP, Pulla V, Clark M, Mariscal ES, Ponnuswami I, editors. Advancing social work in mental health through strengths-based practice. London: Primrose Hall Publishing; 2014. p. 177-204. 
26. Järvikoski A. Monimuotoinen kuntoutus ja sen käsitteet. Sosiaali- ja terveys-ministeriön raportteja ja muistioita [The many forms of rehabilitation and the concepts they employ: reports and memoranda by the Ministry of Health and Social Affairs]. Sosiaali- ja terveysministeriö [Ministry of Health Social Affairs]. 2013.

27. Brown A, Bimrose J. Model of learning for career and labour market transitions. Res Comp Int Educ. 2014;9(3):270-86. https://doi.org/10.2304/rcie.2014.9.3. 270.

28. Savinainen M, Seitsamo J, Joensuu M. The association between changes in functional capacity and work ability among unemployed individuals. Int Arch Occup Environ Health. 2019;93(4):503-11. https://doi.org/10.1007/ s00420-019-01498-1.

29. World Health Organization (WHO). International classification of functioning, disability and health: ICF. Geneva: WHO; 2001.

30. Lightfoot E. Community-based rehabilitation: a rapidly growing method for supporting people with disabilities. Int Soc Work. 2004;47(4):455-68. https://doi.org/10.1177/ 0020872804046253.

31. Thomas M. Reflections on community-based rehabilitation. Psychol Dev Soc. 2011;23(2):277-91. https://doi.org/10. 1177/097133361102300206.

32. World Health Organization (WHO). CBR: a strategy for rehabilitation, equalisation of opportunities, poverty reduction and social inclusion of people with disabilities. Joint Position Paper 2004. 2004. https://apps.who.int/iris/ bitstream/handle/10665/43060/9241592389_eng. pdf? sequence $=1 \&$ isAllowed $=y$.

33. World Health Organization (WHO). Community-based rehabilitation: CBR guidelines. 2019. https://www.who.int/ disabilities/cbr/guidelines/en/.

34. Chamberlin J. A working definition of empowerment. Psychiatr Rehabil J. 1997;20(4):43-6.

35. O'Brien L. Pre-vocational group intervention program for building motivation in mature aged unemployed people with a disability. J Rehabil. 2007;73(1):22-8.

36. Oxoby O. Understanding social inclusion, social cohesion, and social capital. Int J Soc Econ. 2009;36(12):1133-52. https://doi.org/10.1108/03068290910996963.

37. Sarvimäki A, Stenbock-Hult B. Hoitotyön etiikka [The ethics of care work]. Edita. 2009.

38. Harju A. Aktiivisten kansalaisten Suomi. [Active citizens' Finland]. Oikeusministeriö. 2004. http://julkaisut. valtioneuvosto.fi/bitstream/handle/10024/75839/omju_ 2004_11_aktiivisten_kansalaisten_suomi.pdf?sequence $=1$.

39. Finnish Government. The Act on Rehabilitative Work (189/ 2001). 2014b. https://www.finlex.fi/fi/laki/ajantasa/2001/ 20010189\#L5.

40. Ministry of Health and Social Affairs. Sosiaalinen kuntoutus [Social rehabilitation]. 2019. https://stm.fi/sosiaalinenkuntoutus.
41. Prieur A, Sharland ESE, Hillyard S, White S. Academy of Finland review report. Soc Sci. 2018. Unpublished.

42. Alaja A, Kajanoja J. Paltamo full employment experiment in Finland: a neo-chartalist job guarantee pilot program? In: Murray MJ, Forstater M, editors. The job guarantee and modern money theory Realizing Keynes's labor standard. London: Palgrave Macmillan; 2017. p. 149-70.

43. Padgett DK. Qualitative methods in social work research. 3rd ed. Thousand Oaks: SAGE; 2016.

44. Tuomi J, Sarajärvi A. Laadullinen tutkimus ja sisällönanalyysi [Qualitative research and content analysis]. Hansaprint Oy. 2013.

45. Miles MB, Huberman AM. Qualitative data analysis: a methods sourcebook. 2nd ed. Thousand Oaks: SAGE; 1994.

46. Sandelowski M. Qualitative analysis: what it is and how do begin. Res Nurs Health. 1995;18(4):371-5. https://doi.org/ 10.1002/nur.4770180411.

47. Saari J. Huono-osaiset. Elämän edellytykset yhteiskunnan pohjalla [The deprived: The prerequisites of life at the bottom level of society]. Gaudeamus. 2015.

48. Grills N, Varghese J. Disability and community-based rehabilitation. In: Khasnabis C, Motsch KH, editors. Community-based rehabilitation: CBR guidelines. Geneva: World Health Organization; 2010. p. 404-17.

49. Biggeri M, Deepak S, Mauro V, Trani J-F, Kumar J, Ramasamy P. Do community-based rehabilitation programmes promote the participation of persons with disabilities? A case control study from Mandya District, India. Disabil Rehabil. 2014;36(18):1508-17. https://doi.org/10. 3109/09638288.2013.823244.

50. Cleaver S, Nixon S. A scoping review of 10 years of published literature on community-based rehabilitation. Disabil Rehabil. 2014;36(17):1385-94. https://doi.org/10.3109/ 09638288.2013.845257.

51. Magnusson D, Roe M, Hartman J. Community perspectives: evaluation of a community-based rehabilitation program in Southern Belize one-year post-implementation. Disabil Rehabil. 2017;39(21):2190-7. https://doi.org/10.1080/ 09638288.2016.1219399.

52. Snyder CR. The psychology of hope: You can get there from here. Mumbai: Free Press; 1994.

53. Wulfgramm M. Can activating labour market policy offset the detrimental life satisfaction effect of unemployment? Socio-Econ Rev. 2011;9(3):477-501. https://doi.org/10. 1093/ser/mwr006.

54. Johnson RW, Mommaerts C. Age differences in job loss, job search, and reemployment. Washington: Urban Institute; 2010 .

Publisher's Note Springer Nature remains neutral with regard to jurisdictional claims in published maps and institutional affiliations. 